\title{
Current Pharmacologic Strategies for Treatment of Intractable Epilepsy in Children
}

\author{
Ja Un Moon ${ }^{1}$, Kyung-Ok Cho ${ }^{2}$ \\ ${ }^{1}$ Department of Pediatrics, College of Medicine, The Catholic University of Korea, Seoul, Korea \\ ${ }^{2}$ Department of Pharmacology, Department of Biomedicine and Health Sciences, Catholic Neuroscience Institute, Institute of Aging and Metabolic Diseases, \\ College of Medicine, The Catholic University of Korea, Seoul, Korea
}

Epileptic encephalopathy (EE) is a devastating pediatric disease that features medically resistant seizures, which can contribute to global developmental delays. Despite technological advancements in genetics, the neurobiological mechanisms of EEs are not fully understood, leaving few therapeutic options for affected patients. In this review, we introduce the most common EEs in pediatrics (i.e., Ohtahara syndrome, Dravet syndrome, and Lennox-Gastaut syndrome) and their molecular mechanisms that cause excitation/inhibition imbalances. We then discuss some of the essential molecules that are frequently dysregulated in EEs. Specifically, we explore voltage-gated ion channels, synaptic transmission-related proteins, and ligand-gated ion channels in association with the pathophysiology of Ohtahara syndrome, Dravet syndrome, and Lennox-Gastaut syndrome. Finally, we review currently available antiepileptic drugs used to treat seizures in patients with EEs. Since these patients often fail to achieve seizure relief even with the combination therapy, further extensive research efforts to explore the involved molecular mechanisms will be required to develop new drugs for patients with intractable epilepsy.

Keywords: Intractable epilepsy; Antiepileptic drugs; Ohtahara syndrome; Dravet syndrome; Lennox-Gastaut syndrome

- Fund/Grant Support: This study was supported by the National Research Foundation of Korea (NRF) (grant nos. 2019R1A2C1003958, 2019K2A9A2A08000167 to KOC).

- Conflict of Interest: No potential conflict of interest relevant to this article was reported.

\section{INTRODUCTION}

Epilepsy is one of the most common neurological disorders and is characterized by recurrent, unprovoked seizures. The new epilepsy definition proposed by the International League Against Epilepsy includes patients with $\geq 2$ unprovoked seizures separated by at least 24 hours, one unprovoked seizure with a probability of further seizure recurrence $>60 \%$, or an identified epilepsy syndrome [1]. The incidence of epilepsy shows a U-shaped pattern with 2 peaks in infancy and in elderly patients [2]. Epilepsy frequently occurs in children, especially during the first year of life [3]. Although approximately twothirds of pediatric patients with epilepsy can be successfully controlled with appropriate antiepileptic drugs (AEDs) and achieve sustained seizure freedom, the remaining one-third suffers from uncontrolled epilepsy even with a combination of AEDs; these patients are diagnosed with refractory epilepsy [4]. Given that brain development is actively ongoing in childhood, refractory epilepsy in children is a serious problem that severely affects the patients' quality of life. Moreover, refractory epilepsy frequently contributes to high mortality and a wide variety of morbidities, including impaired intellectual, behavioral, and so-

Corresponding author: Kyung-Ok Cho (iD https://orcid.org/0000-0002-1314-7584 Department of Pharmacology, College of Medicine, The Catholic University of Korea, 222 Banpo-daero, Seocho-gu, Seoul 06591, Korea Email: kocho@catholic.ac.kr

Submitted: March 27, 2021 / Accepted after revision: May 2, 2021 
cial outcomes as well as developmental stagnation or regression [5], which require intensive investigation. Therefore, in this review, we introduce the 3 most common intractable epilepsy syndromes in children: Ohtahara syndrome (OS) during the neonatal period, Dravet syndrome (DS) in infancy, and Lennox-Gastaut syndrome (LGS) in childhood and adolescence. In addition, we cover current knowledge on the molecular pathophysiology and treatment strategies for epileptic encephalopathies (EEs) in childhood.

\section{COMMON CHILDHOOD EPILEPTIC ENCEPHALOPATHIES}

\section{Ohtahara Syndrome}

OS, which is also known as early infantile epileptic encephalopathy with burst-suppression, is the earliest developing age-dependent EE diagnosed in children (Table 1). Seizures appear during the first 3 months of life, frequently within 10 days of birth [6]. The seizure phenotype includes mostly tonic spasms with or without clustering regardless of the type of sleep cycle.
The electroencephalogram (EEG) pattern is characterized by a periodic burst-suppression pattern during both waking and sleeping states, which is critical for diagnosis of OS. Most seizures in OS patients are intractable to conventional AEDs, which contributes to the very poor prognosis seen in this disorder. Half of OS patients die within the first year of life, while the survivors commonly develop profound psychomotor impairments and significant intellectual disabilities [7]. As the child ages, OS often transforms into West Syndrome, while a far fewer number evolves into LGS [6,7]. The underlying etiology of OS patients is very heterogeneous, ranging from genetic defects, mitochondrial abnormalities, and metabolic disability to structural abnormalities of the brain [6]. However, the neurobiological backgrounds of OS patients are largely unknown, as only a few studies have shown a possible link between genetic mutations, such as voltage-gated sodium channel a2 (SCN2A), voltage-gated potassium channel subfamily Q member 2 (KCNQ2), Aristaless-related homeobox, syntaxin-binding protein 1 (STXBP1), and cyclin-dependent kinase-like 5, and OS pathophysiology $[8,9]$.

Table 1. Summary of the most common epileptic encephalopathies in pediatrics

\begin{tabular}{|c|c|c|c|}
\hline Syndrome & Clinical features & Gene mutations & Pharmacological therapy \\
\hline Ohtahara syndrome & $\begin{array}{l}\text { Age of onset: } 0-3 \text { months } \\
\text { EEG: periodic burst-suppression pattern } \\
\text { during both waking and sleeping states } \\
\text { Seizure type: tonic spasms with or without } \\
\text { clustering }\end{array}$ & $\begin{array}{l}\text { Voltage-gated ion channel: SCN2A, } \\
\text { KCNQ2 } \\
\text { Synaptic transmission-related protein: } \\
\text { STXBP1 } \\
\text { Others: ARX, CDKL5 }\end{array}$ & $\begin{array}{l}\text { Extremely resistant to AEDs } \\
\text { Beneficial: vigabatrin, valproic acid }\end{array}$ \\
\hline Dravet syndrome & $\begin{array}{l}\text { Age of onset: first year of life } \\
\text { EEG: normal for first 1-2 years; generalized } \\
\text { and multifocal epileptiform abnormalities } \\
\text { Seizure type: generalized clonic or } \\
\text { hemiclonic seizures; followed by } \\
\text { myoclonic, absence, focal, generalized } \\
\text { tonic-clonic, and atonic drop seizures }\end{array}$ & $\begin{array}{l}\text { Voltage-gated ion channel: SCN1A, } \\
\text { SCN2A, SCN8A, SCN1B, KCNA2, HCN1 } \\
\text { Synaptic transmission-related protein: } \\
\text { STXBP1 } \\
\text { Ligand-gated ion channel: GABRA1, } \\
\text { GABARG2 } \\
\text { Others: CHD2, PCDH19 }\end{array}$ & $\begin{array}{l}\text { 1st line: clobazam combined with } \\
\text { valproic acid } \\
\text { 2nd line: stiripentol } \\
\text { Beneficial: levetiracetam, } \\
\text { lamotrigine }\end{array}$ \\
\hline $\begin{array}{l}\text { Lennox-Gastaut } \\
\text { syndrome }\end{array}$ & $\begin{array}{l}\text { Age of onset: } 1-7 \text { years } \\
\text { EEG: bursts of slow spike waves or } \\
\text { generalized paroxysmal fast activities } \\
\text { Seizure type: atypical absence, atonic or } \\
\text { drop attacks, tonic, myoclonic, and gener- } \\
\text { alized tonic-clonic seizures }\end{array}$ & $\begin{array}{l}\text { Voltage-gated ion channel: SCN1A, } \\
\text { SCN2A, SCN8A } \\
\text { Synaptic transmission-related protein: } \\
\text { STXBP1 } \\
\text { Ligand-gated ion channel: GABRB3, } \\
\text { GRIN2B } \\
\text { Others: CHD2, FOXG1, DNM1 }\end{array}$ & $\begin{array}{l}\text { 1st line: valproic acid } \\
\text { 2nd line: lamotrigine (in association } \\
\text { with valproic acid) } \\
\text { Beneficial: rufinamide, perampanel, } \\
\text { felbamate }\end{array}$ \\
\hline
\end{tabular}

AEDs, antiepileptic drugs; EEG, electroencephalogram; SCN2A, voltage-gated sodium channel a2 subunit; KCNQ2, voltage-gated potassium channel subfamily Q member 2; STXBP1, syntaxin-binding protein 1; ARX, Aristaless-related homeobox; CDKL5, cyclin-dependent kinase-like 5; SCN1A, voltage-gated sodium channel $\alpha 1$ subunit; SCN8A, voltage-gated sodium channel $\alpha 8$ subunit; SCN1B, voltage-gated sodium channel $\beta 1$ subunit; KCNA2, voltage-gated potassium channel subfamily A member 2; HCN, hyperpolarization-activated cyclic nucleotide-gated channel 1; GABRA1, $\gamma$-aminobutyric acid type A receptor $\alpha 1$ subunit; GABARG2, $\gamma$-aminobutyric acid type A receptor $\gamma 2$ subunit; CHD, chromodomain helicase DNA-binding protein 2; PCDH19, protocadherin-19; GABRB3, $\gamma$-aminobutyric acid type A receptor $\beta 3$ subunit; GRIN2B, glutamate ionotropic receptor N-methyl-D-aspartate type subunit 2B; FOXG1, forkhead box G1; DNM1, dynamin 1. 


\section{Dravet Syndrome}

DS is a well-known, medically intractable type of epilepsy that is characterized by frequent episodes of prolonged seizures (Table 1). DS usually presents in the first year of life with generalized clonic or hemiclonic seizures triggered by fever [10]. Gradually, multifarious seizure types (including myoclonic, absence, focal, generalized tonic-clonic, and atonic drop seizures) can appear between the ages of 1 and 4 years [11]. Although development is normal in the first year of life, intellectual, behavioral, and motor disabilities become apparent from the second year of life [11].

About $75 \%-80 \%$ of patients diagnosed with DS have a de novo mutation within the gene for sodium channel al subunit (SCN1A), a voltage-gated sodium channel. The location and the features of the mutation in this $S C N 1 A$ gene are quite varied and can include a nonsense mutation, a missense mutation, a frameshift mutation, a splice-site mutation, and gross chromosomal rearrangements $[12,13]$. Several other genes, such as the a1 subunit and the $\gamma 2$ subunit of the $\gamma$-aminobutyric acid (GABA) type A receptor (GABRA1, GABARG2), hyperpolarization-activated cyclic nucleotide-gated channel 1, voltage-gated potassium channel subfamily A member 2 (KCNA2), chromodomain helicase DNA-binding protein 2 (CHD2), STXBP1, SCN2A, voltage-gated sodium channel $\alpha 8$ and $\beta 1$ subunits (SCN8A and SCN1B), and protocadherin-19, have been reported in DS patients where SCN1A mutations were not found, which suggests that complex molecular mechanisms underlie DS pathophysiology $[9,14,15]$.

\section{Lennox-Gastaut Syndrome}

LGS is a rare but severe EE that accounts for $1 \%-10 \%$ of all cases in children [16,17]. LGS patients start to show seizures usually between 1 and 7 years of age, which progressively aggravates their normal development (Table 1). Phenotypically, multiple seizure types are often seen, including atypical absence, atonic or drop attacks, tonic, myoclonic, and generalized tonicclonic seizures. During these seizures, bursts of slow spike waves or generalized paroxysmal fast activities can be detected on EEG [16]. LGS is defined by the triad of multiple drug-resistant seizure types, characteristic abnormal EEG findings, and intellectual disability [16].

The etiology of LGS can be either identifiable (genetic-structural-metabolic) or unknown [17]. Identifiable etiologies account for $65 \%-75 \%$ of cases and are derived mainly from diffuse cerebral injuries, including tuberous sclerosis complex, infec- tions (such as meningitis and encephalitis), birth injury/trauma, developmental brain malformations, and hereditary metabolic disorders. The remaining $25 \%$ of patients can be classified with an unknown (cryptogenic) type of LGS. Although the molecular mechanisms of LGS are largely unknown, several genetic studies have found de novo mutations in certain genes, including SCN1A, SCN2A, SCN8A, glutamate ionotropic receptor N-methyl-D-aspartate (NMDA) type subunit 2B (GRIN2B), STXBP1, CHD2, forkhead box G1, dynamin 1 , and the $\beta 3$ subunit of the GABA type A receptor (GABRB3) [9].

\section{MOLECULAR MECHANISMS OF INTRACTABLE PEDIATRIC EPILEPSIES}

Our current understanding of the molecular mechanisms of EEs in pediatrics remains in its infancy. Although the advent of molecular genetics has shed light on clues about crucial players responsible for the excitation/inhibition (E/I) balance in the brain, there is a lack of consistent experimental models that recapitulate all the critical clinical features. In this review, we briefly explain the basic molecular mechanisms of the E/I imbalance that causes seizures in association with key molecules known to be deregulated in intractable epilepsies in children (Table 1).

\section{The E/I Imbalance}

The pathophysiological mechanisms that lead to seizures are grounded in hyperexcitability resulting from an E/I imbalance at single-cell and at network levels. Excessive excitation, reduced inhibition, or both can attribute to a hyperexcitable and hypersynchronous state of the brain that can increase the propensity for seizures [18].

At the cellular level, the action potential is propagated by changing the currents of voltage-gated ion channels in both excitatory and inhibitory neurons. In particular, opening of voltage-gated sodium channels can lead to membrane depolarization, followed by rapid inactivation. During membrane depolarization, potassium channels open, resulting in membrane hyperpolarization that requires more time to generate new action potentials. Sodium channels then recover from their inactivated state as the membrane potential is fully repolarized. Under physiological conditions, the refractory period derived from sodium channel inactivation to potassium current-induced membrane hyperpolarization can cause neurons to be unaffected by depolarizing signals. Therefore, any changes to 
promote membrane depolarization or to reduce the refractory period can lead to excessive excitation of neurons.

An individual neuron with a robust action potential can activate adjacent neurons, causing numerous neurons to discharge simultaneously [19]. Activation of voltage-gated calcium channels promotes the release of neurotransmitters as well as neuronal depolarization. Once neurotransmitters (including glutamate and GABA) are released, various postsynaptic ligand-gated ion channels can be activated, modulating signal transmission. For example, NMDA and a-amino-3-hydroxyl-5-methyl4-isoxazole-propionate (AMPA) receptors contribute to generate postsynaptic excitatory potentials and thereby recruit additional excitatory neurons to be activated [20]. In contrast, GABA receptors can prevent neuronal hyperexcitability by increasing chloride currents that help to escalate the action potential threshold of postsynaptic neurons, mediating any surrounding inhibition [21]. Thus, either activation of glutamate receptors or inhibition of GABAergic neurotransmission at the network level can lead to a hyper-synchronization state of the brain, which is prone to seizure generation.

\section{Potential Molecular Mechanisms Associated With Intractable Epilepsies in Children}

In this part of the review, we introduce essential voltage-gated ion channels, synaptic transmission-related proteins, and ligand-gated ion channels that are dysregulated in OS, DS, and LGS and are thought to contribute to the accompanying E/I imbalance in the brain (Fig. 1).

\section{Voltage-Gated Sodium Channels}

Voltage-gated sodium channels are composed of an a subunit encoded by 9 genes (SCN1A, SCN2A, SCN3A, SCN4A, SCN5A, $S C N 8 A, S C N 9 A, S C N 10 A$, and SCN11) and one or more $\beta$ subunits that are encoded by 4 genes (SCN1B-SCN4B) [22]. Mutations in SCN1A, SCN2A, SCN8A, and SCN1B have been reported in EEs [9]. SCN1A mutation (encoding $\mathrm{Na}_{\mathrm{v}} 1.1$ ) is one of the most crucial causative genes in DS and LGS [9]. Nav1.1 is expressed widely both in excitatory neurons and in interneurons located in the neocortex, hippocampus, and cerebellum [23]. Interestingly, previous studies that have used SCN1A knockout mice and induced pluripotent stem cell-derived neurons from DS patients have described that loss-of-function (LOF) of $\mathrm{Na}_{\mathrm{v}} 1.1$ (especially in GABAergic-inhibitory neurons) leads to hyperexcitability of excitatory neurons due to deficits in action potential firing of the interneurons, which is known as the "interneuron hypothesis" [24-26]. However, another study that used DS patient-derived neurons reported an increased sodium current in multiple cell types including both GABAergic interneurons and glutamatergic neurons based on morphology [27]. Thus, further studies are required for a clear understanding of DS pathophysiology. With regard to the $\beta$ subunit of voltage-gated sodium channels, SCN1B mutations have been reported mainly in patients with DS [28,29]. SCN1B-based mouse models of DS demonstrated a heightened susceptibility to seizures [29] with the increased action potential firing in excitatory pyramidal neurons but no changes in interneurons [30]. Considering all these seemingly discordant reports, it can be inferred that seizures arise from multiple functional defects of voltage-gated sodium channels that can trigger an E/I imbalance.

\section{Voltage-Gated Potassium Channels}

Voltage-gated potassium channels are composed of $4 a$ subunits that form the channel pore and auxiliary $\beta$ subunits [31]. There are 12 subfamilies $\left(\mathrm{K}_{\mathrm{v}} 1-12\right)$ of voltage-gated potassium channels that display approximately $40 \alpha$ subunits [31]. Mutations in several potassium channel genes, including KCNA2 $\left(\mathrm{K}_{\mathrm{v}} 1.2\right), \mathrm{KCNB} 1\left(\mathrm{~K}_{\mathrm{v}} 2.1\right)$, and $\mathrm{KCNQ} 2\left(\mathrm{~K}_{\mathrm{v}} 7.2\right)$, have been associated with EEs [32,33]. $K_{v} 2.1$ is expressed in both pyramidal neurons and interneurons and mediates delayed rectifier potassium current $[34,35]$. By inducing membrane repolarization, $\mathrm{K}_{\mathrm{v}} 2.1$ can suppress high-frequency neuronal firing [36]. Although a previous study that used $\mathrm{K}_{\mathrm{v}} 2.1$ knockout mice showed no spontaneous seizures, $\mathrm{K}_{\mathrm{v}} 2.1$ deletion exhibited hypersensitivity to chemo-convulsant injections, in addition to accelerating seizure progression [35]. Other genes, such as KCNQ2 or $\mathrm{KCNQ3}$, can cause either a homogeneous $\left(\mathrm{K}_{\mathrm{v}} 7.2\right)$ or a heterogeneous $\left(\mathrm{K}_{\mathrm{v}} 7.2 / \mathrm{K}_{\mathrm{v}} 7.3\right)$ complex to become co-localized at the axon's initial segment [37]. $\mathrm{K}_{\mathrm{v}} 7.2$ or $\mathrm{K}_{\mathrm{v}} 7.2 / \mathrm{K}_{\mathrm{v}} 7.3$ complexes can form low-threshold voltage-gated $\mathrm{K}^{+}$channels or M-channels and regulate the neuronal membrane potential via slow, noninactivating muscarinic currents [38]. Thus, open state of $\mathrm{K}_{\mathrm{v}} 7.2$ or $\mathrm{K}_{\mathrm{v}} 7 \cdot 2 / \mathrm{K}_{\mathrm{v}} 7.3$ complexes can inhibit initiation of the action potential and suppress repetitive neuronal firing [38,39]. This notion was supported by a mouse line that showed spontaneous mutations involving KCNQ2, demonstrating increased neuronal excitability [40]. Therefore, deficits in membrane repolarization through mutated voltage-gated potassium channels might cause a failure of natural antiepileptic mechanisms of the brain and lead to an $\mathrm{E} / \mathrm{I}$ imbalance. 


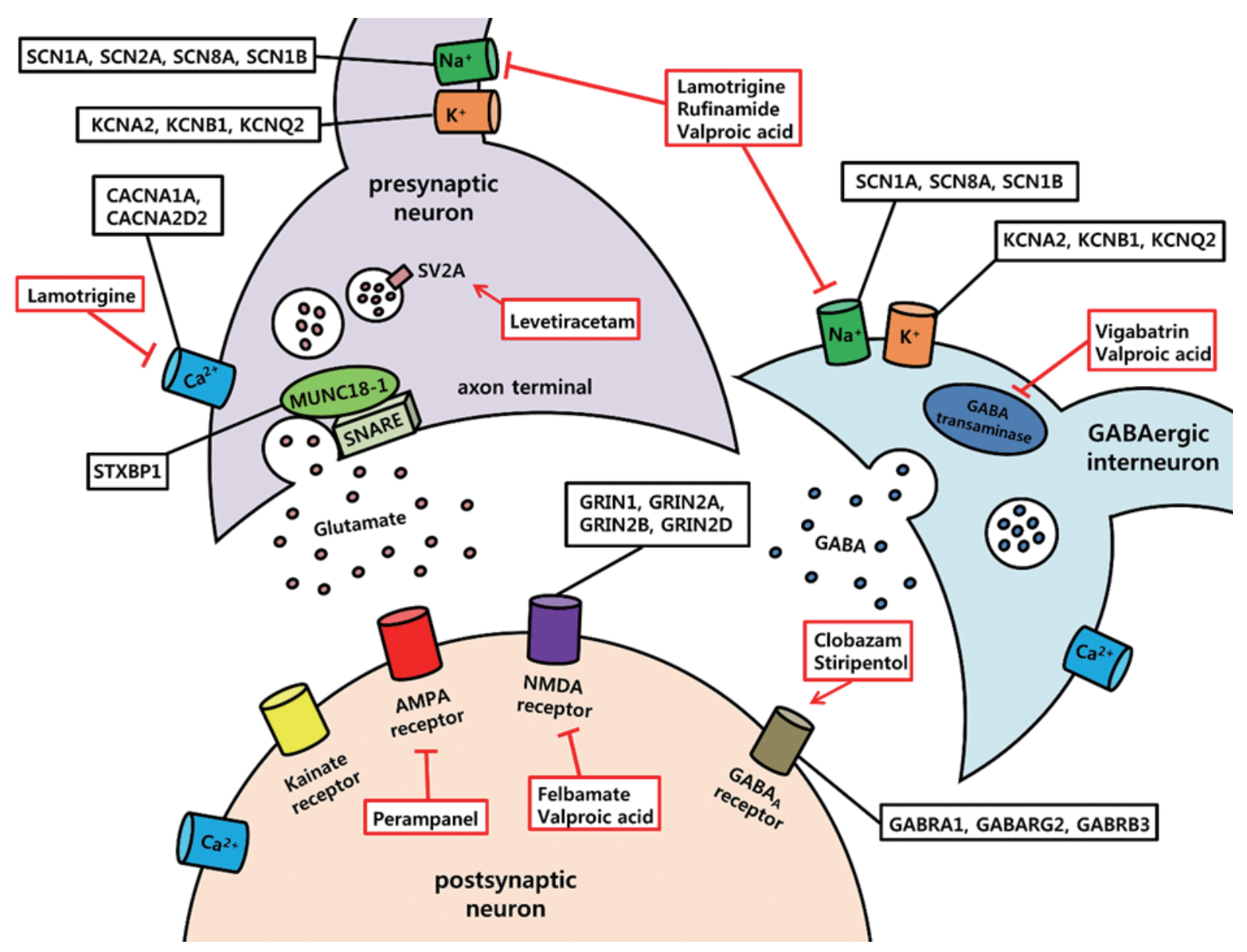

Fig. 1. Essential molecular targets and antiepileptic drugs in intractable pediatric epilepsies. Voltage-gated ion channels (sodium, potassium, and calcium), synaptic transmission-related proteins, and ligand-gated ion channels (glutamate receptors, $\gamma$-aminobutyric acid type A receptor) are frequently mutated in epileptic encephalopathies. Examples of mutated genes in Ohtahara syndrome, Dravet syndrome, and Lennox-Gastaut syndrome are described in black box. In addition, crucial antiepileptic drugs that are currently available for epileptic encephalopathies are illustrated in red box. Red arrow indicates potentiating effects by drugs, and red lines with blunt ends indicate inhibitory action of drugs. SCN1A, voltage-gated sodium channel $\alpha 1$ subunit; SCN2A, voltage-gated sodium channel a2 subunit; SCN8A, voltage-gated sodium channel a8 subunit; SCN1B, voltage-gated sodium channel $\beta 1$ subunit; KCNA2, voltagegated potassium channel subfamily A member 2; KCNB1, voltage-gated potassium channel subfamily B member 1; KCNQ2, voltagegated potassium channel subfamily Q member 2; CACNA1A, voltage-gated calcium channel subunit alpha 1A; CACNA2D2, voltagegated calcium channel auxillary subunit alpha 2 delta 2; SV2A, synaptic vesicle glycoprotein 2A; SNARE, soluble $N$-ethylmaleimide sensitive factor attachment protein receptor; STXBP1, syntaxin-binding protein 1; AMPA, $\alpha$-amino-3-hydroxy-5-methyl-4isoxazolepropionic acid; NMDA, $N$-methyl-D-aspartate; GABA, $\gamma$-aminobutyric acid; GRIN1, glutamate ionotropic receptor $N$ methyl-D-aspartate type subunit 1; GRIN 2A, glutamate ionotropic receptor $N$-methyl-D-aspartate type subunit 2A; GRIN2B, glutamate ionotropic receptor $N$-methyl-D-aspartate type subunit 2B; GRIN2D, glutamate ionotropic receptor $N$-methyl-D-aspartate type subunit 2D; GABRA1, $\gamma$-aminobutyric acid type A receptor $\alpha 1$ subunit; GABARG2, $\gamma$-aminobutyric acid type A receptor $\gamma 2$ subunit; GABRB3, $\gamma$-aminobutyric acid type A receptor $\beta 3$ subunit.

\section{Voltage-Gated Calcium Channels}

Voltage-gated calcium channels are classified into 2 major groups based on threshold of membrane action potential: high voltage-activated (HVA) calcium channels (L-, N-, P-, Q-, Rtypes) and low voltage-activated calcium channels (T-type)
[41]. Each voltage-gated calcium channel consists of an $\alpha 1$ subunit that forms the pore, a complex of $\alpha 2$ and $\delta$ subunits, an intracellular $\beta$ subunit, and (in some cases) a $\gamma$ subunit [41]. While L-type calcium currents play major roles in excitation of postsynaptic neurons, N-, P/Q-, and R-type calcium currents are 
involved in rapid synaptic neurotransmitter release [42]. In LGS and $O S$, mutations in calcium voltage-gated channel subunit alpha $1 \mathrm{~A}(\mathrm{CACNA} 1 \mathrm{~A})$ and calcium voltage-gated channel auxiliary subunit alpha 2 delta 2 (CACNA2D2) have been reported [9]. In particular, CACNA1A encodes the al subunit of the P/ $\mathrm{Q}$ type calcium channel, which is important for neurotransmitter release. As expected, CACNA1A LOF mutations in cortical interneurons demonstrated reduced GABA release, supporting the severe epileptic phenotype in mutant mice [43]. Thus, impaired ability of CACNA1A might contribute to cellular excitability and produce seizures resulting from increased neuronal firing by altering inhibitory neurotransmission.

\section{Syntaxin-Binding Protein 1}

A continuous cycle of synaptic vesicle formation, presynaptic neurotransmitter release, synaptic vesicle recycling, and activation of postsynaptic receptors is essential for synaptic transmission [44]. Multiple molecular players (such as dynamin, synaptic vesicle glycoprotein $2 \mathrm{~A}$ (SV2A), synapsin, and syntaxin) are involved in this multistep process [45-47]. The STXBP1 gene encodes the presynaptic protein MUNC18-1, which is a trafficking protein that regulates synaptic vesicle docking and fusion through interactions with the soluble $\mathrm{N}$-ethylmaleimide sensitive factor attachment protein receptor (SNARE) complex and plays a critical role in neurotransmitter secretion [48-51]. STXBP1 mutations have been shown to cause EEs, including DS, LGS, and OS [9]. Decreased expression of STXBP1 can reduce the synaptic vesicle pool size, which is more common in interneurons than in glutamatergic neurons [49,51], suggesting a net hyperexcitability leading to seizures.

\section{Glutamate Receptors}

Glutamate receptors are grouped into 2 families: (1) ligand-gated ion channels that produce excitatory postsynaptic currents and (2) metabotropic receptors that are G protein-coupled receptors [52]. Three subtypes of ionotropic glutamate receptors are further classified: AMPA receptors (GluA1-GluA4), kainate receptors (GluK1-GluK5), and NMDA receptors (GluN1, GluN2A-GluN2D, GluN3A, and GluN3B). Among these, epilepsyrelated mutations in glutamate receptors include GRIN1, GRIN2A, GRIN2B, and GRIN2D, which encode the GluN1, GluN2A, GluN2B, and GluN2D subunits, respectively. Specifically, GRIN2B mutations have been identified in patients with LGS and West Syndrome [9]. However, little is known about the neurobiological impact of these mutations in EEs, which war- rants further investigation.

\section{GABA Type A (GABA $\left.A_{A}\right)$ Receptors}

$\mathrm{GABA}_{\mathrm{A}}$ receptors are ligand-gated ionotropic receptors that can mediate phasic (synaptic) or tonic (extrasynaptic) inhibitory neurotransmissions by allowing inward chloride flow causing postsynaptic hyperpolarization [53]. Structurally, heteropentameric $\mathrm{GABA}_{\mathrm{A}}$ receptors are composed of various combinations of subunits ( $\alpha 1-6, \beta 1-3, \gamma 1-3, \delta, \varepsilon, \theta$, and $\rho 1-3$ ); the most abundant subtype contains $2 \alpha$-, $2 \beta$-, and $1 \gamma$-subunit [53]. In DS, OS, and LGS, de novo mutations of the $\mathrm{GABA}_{\mathrm{A}}$ receptor genes GABRA1, GABRG2, and GABRB3 that encode the $\alpha 1, \gamma 2$, and $\beta 3$ subunits, respectively, have been reported $[9,14,15,54,55]$. Impaired GABAergic inhibition by GABRA1 mutations could reduce the total surface expression of $\mathrm{GABA}_{\mathrm{A}}$ receptors in addition to decreasing the effectiveness of neurotransmitters [56]. Compared to GABRA1, GABRG2 plays several complicated roles, given that heterozygous GABRG2 knockout mice demonstrated an absence of seizures, while heterozygous GABRG2 knock-in mice showed more severe epilepsy phenotypes [57,58]. Finally, the GABRB3 mutations present in patients with LGS reduced GABA-evoked currents by disrupting the GABA binding site but led to no changes in the surface expression of $\mathrm{GABA}_{\mathrm{A}}$ receptors [55]. Similarly, GABRB3 knock-in mice showed reduced inhibitory postsynaptic currents with no alteration in $\mathrm{GABA}_{\mathrm{A}}$ receptor trafficking [59]. Collectively, disruption of $\mathrm{GABA}_{\mathrm{A}}$ receptor subunits can impair network-level surrounding inhibition and cause susceptibility to seizures.

\section{PHARMACOLOGICAL APPROACHES TO INTRACTABLE EPILEPSIES IN PEDIATRIC PATIENTS}

Most patients with EEs (including OS, DS, and LGS) are highly refractory to AEDs, so a combination therapy of more than 2 AEDs is recommended. Therapeutic strategies are aimed to reduce the frequency of seizures to improve patient quality of life and to minimize the side effects of AEDs. Many currently available AEDs are designed to restore the E/I balance in the brain and include drugs that can modulate voltage-gated ion channels, those that can modulate synaptic neurotransmission, drugs that can inhibit glutamate-mediated excitation, substances that can enhance GABA-mediated inhibition, and drugs that have multiple mechanisms (Fig. 1, Table 1). 


\section{Drugs That Modulate Voltage-Gated lon Channels}

Lamotrigine, which is typically combined with valproic acid, has been used for treatment of LGS $[60,61]$. Although the mechanism of lamotrigine is not fully understood, it is thought to stabilize the neuronal membrane by protracting the inactivated state of sodium channels [60]. Another proposed mechanism of lamotrigine is related to inhibition of the HVA calcium channel [62]. These channels can mediate rapid neurotransmitter release by controlling the influx of calcium into the presynaptic terminals [42]. Thus, reduction in HVA calcium currents by lamotrigine can decrease the release of neurotransmitters.

Rufinamide is used as an adjunctive treatment of the seizures that are associated with LGS [63]. This drug also acts on voltage-gated sodium channels by slowing their recovery from the inactive state, thereby limiting the excessive firing of sodiumdependent action potentials in neurons $[64,65]$. Rufinamide also has an additional mechanism that can inhibit a subset of glutamate receptors (such as mGluR5) at higher concentrations, supporting its antiseizure effects [66].

\section{Drugs That Modulate Presynaptic Neurotransmitter Release}

Levetiracetam can be used as an adjunctive treatment for various EEs [67-70]. Its mechanism is related with SV2A, which is mainly located in the presynaptic terminals and promotes synaptic vesicle release and recycling [71,72]. Specifically, levetiracetam can enter the recycling synaptic vesicles and decrease the readily releasable pool of vesicles by inhibiting SV2A and eventually reducing excitatory postsynaptic currents [73]. Interestingly, levetiracetam can decrease activity-dependent neurotransmitter release while sparing the normal synaptic transmission, which reduces the number of potential adverse effects [74].

\section{Drugs That Inhibit Glutamate-Mediated Excitation}

Perampanel is a noncompetitive AMPA receptor antagonist [75] with demonstrated efficacy in refractory epilepsies, including LGS [76,77]. Although definite mechanisms of the antiepileptic effects of perampanel have not been established, the drug is known to promote a closed state of the AMPA receptor, preventing opening of the ion channel [78] and resulting in inhibition of neuronal excitation.

Felbamate has a particular demonstrated efficacy on LGS, which selectively blocks NMDA receptors (including the NR2B subunit) and leads to reduction in glutamatergic transmission [79]. Since the expression of the NR2B subunit is not as wide- spread as that of other subunits throughout the brain, felbamate can reduce the potential side effects derived from inhibition of NMDA receptors. Felbamate can potentiate GABAergic inhibition through allosteric interaction with $\mathrm{GABA}_{\mathrm{A}}$ receptors [79, 80]. In addition, by blocking the sodium channel, felbamate can reduce sustained repetitive firing [81], which suggests that this drug has multiple mechanisms of action [82].

\section{Drugs That Enhance GABA-Mediated Inhibition}

Drugs that enhance GABAergic inhibition mostly target GABAA receptors, GABA metabolic enzymes, or GABA transporters [83]. Clobazam is used frequently as the first-line treatment of DS along with valproic acid or as an adjunctive treatment in LGS [84-86]. Clobazam is a 1,5-benzodiazepine that acts mainly through activation of postsynaptic $\mathrm{GABA}_{\mathrm{A}}$ receptors, inducing phasic inhibition [87].

Stiripentol can be added as a second-line drug for DS [85] and is an aromatic allylic alcohol. Its main mechanism of action is induction of inward chloride currents that are created by increasing the open duration of $\mathrm{GABA}_{\mathrm{A}}$ receptors [88]. This substance can also increase synaptic GABA level through interference in GABA reuptake and metabolism [89].

Vigabatrin showed favorable responses in OS and West Syndrome [90,91]. This drug is an irreversible inhibitor of GABA transaminase that metabolizes GABA into succinic semialdehyde, resulting in the increase of synaptic GABA concentrations [92,93]. Vigabatrin can also enhance tonic inhibition via GABA transporter reversal due to high levels of intracellular GABA [94].

\section{Broad-Spectrum Drugs}

Valproic acid is a pleiotropic drug with multiple mechanisms of action, including inhibition of voltage-gated sodium and T-type calcium channels, potentiation of GABAergic inhibition, and inhibition of NMDA receptor-mediated neuronal excitation [95]. Due to its wide mechanisms of action, valproic acid often is used as an initial treatment in DS and as an adjunctive treatment for LGS and OS $[84,85,96,97]$.

\section{CONCLUSIONS}

Despite recent technological advancements in next-generation sequencing that have identified many new mutations in intractable pediatric EEs, the neurobiological mechanisms linking these mutations and seizure generation are not yet fully appre- 
ciated. In this review, we described the clinical features of the 3 most common EEs and their basic molecular mechanisms with an emphasis on several essential molecules that are dysregulated in OS, DS, and LGS. In addition, we explored the pharmacological options currently available for treating intractable EEs in childhood. Since no effective drug has demonstrated superior efficacy for seizure control in EEs (including OS, DS, and LGS), more extensive research efforts are required to cure these devastating diseases.

\section{AUTHOR CONTRIBUTION STATEMENT}

- Conceptualization: $K O C$

- Data curation: JUM

- Formal analysis: JUM

- Funding acquisition: $K O C$

- Methodology: JUM

- Project administration: KOC

- Visualization: JUM, KOC

- Writing-original draft: JUM, KOC

- Writing-review \& editing: KOC

\section{ORCID}

$\begin{array}{ll}\text { Ja Un Moon } & \text { http://orcid.org/0000-0002-9942-4609 } \\ \text { Kyung-Ok Cho } & \text { http://orcid.org/0000-0002-1314-7584 }\end{array}$

\section{REFERENCES}

1. Fisher RS, Acevedo C, Arzimanoglou A, Bogacz A, Cross JH, Elger $\mathrm{CE}$, et al. ILAE official report: a practical clinical definition of epilepsy. Epilepsia 2014;55:475-82.

2. Fiest KM, Sauro KM, Wiebe S, Patten SB, Kwon CS, Dykeman J, et al. Prevalence and incidence of epilepsy: A systematic review and meta-analysis of international studies. Neurology 2017;88:296-303.

3. Aaberg KM, Gunnes N, Bakken IJ, Lund Soraas C, Berntsen A, Magnus P, et al. Incidence and prevalence of childhood epilepsy: a nationwide cohort study. Pediatrics 2017;139: e20163908.

4. Kwan P, Brodie MJ. Early identification of refractory epilepsy. N Engl J Med 2000;342:314-9.

5. Beghi E, Camfield PR, Camfield CS. Epidemiologic aspects: lost in transition. Epilepsia 2014;55 Suppl 3:3-7.

6. Ohtahara S, Yamatogi Y. Ohtahara syndrome: with special reference to its developmental aspects for differentiating from early myoclonic encephalopathy. Epilepsy Res 2006;70 Suppl 1:S58-67.
7. Yamatogi Y, Ohtahara S. Early-infantile epileptic encephalopathy with suppression-bursts, Ohtahara syndrome; its overview referring to our 16 cases. Brain Dev 2002;24:13-23.

8. Auvin S, Cilio MR, Vezzani A. Current understanding and neurobiology of epileptic encephalopathies. Neurobiol Dis 2016;92:7289.

9. McTague A, Howell KB, Cross JH, Kurian MA, Scheffer IE. The genetic landscape of the epileptic encephalopathies of infancy and childhood. Lancet Neurol 2016;15:304-16.

10. Guerrini R. Dravet syndrome: the main issues. Eur J Paediatr Neurol 2012;16 Suppl 1:S1-4.

11. Dravet C. The core Dravet syndrome phenotype. Epilepsia 2011;52 Suppl 2:3-9.

12. Claes L, Del-Favero J, Ceulemans B, Lagae L, Van Broeckhoven C, De Jonghe P. De novo mutations in the sodium-channel gene SCN1A cause severe myoclonic epilepsy of infancy. Am J Hum Genet 2001;68:1327-32.

13. Wallace RH, Hodgson BL, Grinton BE, Gardiner RM, Robinson R, Rodriguez-Casero $\mathrm{V}$, et al. Sodium channel a1-subunit mutations in severe myoclonic epilepsy of infancy and infantile spasms. Neurology 2003;61:765-9.

14. Carvill GL, Weckhuysen S, McMahon JM, Hartmann C, Moller $\mathrm{RS}$, Hjalgrim $\mathrm{H}$, et al. GABRA1 and STXBP1: novel genetic causes of Dravet syndrome. Neurology 2014;82:1245-53.

15. Marini C, Scheffer IE, Nabbout R, Suls A, De Jonghe P, Zara F, et al. The genetics of Dravet syndrome. Epilepsia 2011;52 Suppl 2:24-9.

16. Arzimanoglou A, French J, Blume WT, Cross JH, Ernst JP, Feucht $\mathrm{M}$, et al. Lennox-Gastaut syndrome: a consensus approach on diagnosis, assessment, management, and trial methodology. Lancet Neurol 2009;8:82-93.

17. Camfield PR. Definition and natural history of Lennox-Gastaut syndrome. Epilepsia 2011;52 Suppl 5:3-9.

18. Engel J Jr. Excitation and inhibition in epilepsy. Can J Neurol Sci 1996;23:167-74.

19. Smith EH, Schevon CA. Toward a mechanistic understanding of epileptic networks. Curr Neurol Neurosci Rep 2016;16:97.

20. Naylor DE, Liu H, Niquet J, Wasterlain CG. Rapid surface accumulation of NMDA receptors increases glutamatergic excitation during status epilepticus. Neurobiol Dis 2013;54:225-38.

21. Prince DA, Wilder BJ. Control mechanisms in cortical epileptogenic foci. "Surround" inhibition. Arch Neurol 1967;16:194-202.

22. de Lera Ruiz M, Kraus RL. Voltage-gated sodium channels: structure, function, pharmacology, and clinical indications. J Med Chem 2015;58:7093-118.

23. Trimmer JS, Rhodes KJ. Localization of voltage-gated ion channels 
in mammalian brain. Annu Rev Physiol 2004;66:477-519.

24. Yu FH, Mantegazza M, Westenbroek RE, Robbins CA, Kalume F, Burton KA, et al. Reduced sodium current in GABAergic interneurons in a mouse model of severe myoclonic epilepsy in infancy. Nat Neurosci 2006;9:1142-9.

25. Cheah CS, Yu FH, Westenbroek RE, Kalume FK, Oakley JC, Potter $\mathrm{GB}$, et al. Specific deletion of $\mathrm{Na}_{\mathrm{v}} 1.1$ sodium channels in inhibitory interneurons causes seizures and premature death in a mouse model of Dravet syndrome. Proc Natl Acad Sci U S A 2012;109: 14646-51.

26. Sun Y, Pasca SP, Portmann T, Goold C, Worringer KA, Guan W, et al. A deleterious $\mathrm{Na}_{\mathrm{v}} 1.1$ mutation selectively impairs telencephalic inhibitory neurons derived from Dravet Syndrome patients. Elife 2016;5: e13073.

27. Liu Y, Lopez-Santiago LF, Yuan Y, Jones JM, Zhang H, O’Malley $\mathrm{HA}$, et al. Dravet syndrome patient-derived neurons suggest a novel epilepsy mechanism. Ann Neurol 2013;74:128-39.

28. Patino GA, Claes LR, Lopez-Santiago LF, Slat EA, Dondeti RS, Chen $\mathrm{C}$, et al. A functional null mutation of $S C N 1 B$ in a patient with Dravet syndrome. J Neurosci 2009;29:10764-78.

29. Kruger LC, O’Malley HA, Hull JM, Kleeman A, Patino GA, Isom LL. $\beta 1-\mathrm{C} 121 \mathrm{~W}$ is down but not out: epilepsy-associated Scn1b$\mathrm{C} 121 \mathrm{~W}$ results in a deleterious gain-of-function. J Neurosci 2016; 36:6213-24.

30. Reid CA, Leaw B, Richards KL, Richardson R, Wimmer V, Yu C, et al. Reduced dendritic arborization and hyperexcitability of pyramidal neurons in a Scn1b-based model of Dravet syndrome. Brain 2014; 137:1701-15.

31. Allen NM, Weckhuysen S, Gorman K, King MD, Lerche H. Genetic potassium channel-associated epilepsies: Clinical review of the $\mathrm{K}_{\mathrm{v}}$ family. Eur J Paediatr Neurol 2020;24:105-16.

32. Thiffault I, Speca DJ, Austin DC, Cobb MM, Eum KS, Safina NP, et al. A novel epileptic encephalopathy mutation in KCNB1 disrupts Kv2.1 ion selectivity, expression, and localization. J Gen Physiol 2015;146:399-410.

33. Weckhuysen S, Mandelstam S, Suls A, Audenaert D, Deconinck T, Claes LR, et al. KCNQ2 encephalopathy: emerging phenotype of a neonatal epileptic encephalopathy. Ann Neurol 2012;71:15-25.

34. Du J, Tao-Cheng JH, Zerfas P, McBain CJ. The $\mathrm{K}^{+}$channel, Kv2.1, is apposed to astrocytic processes and is associated with inhibitory postsynaptic membranes in hippocampal and cortical principal neurons and inhibitory interneurons. Neuroscience 1998;84:37-48.

35. Speca DJ, Ogata G, Mandikian D, Bishop HI, Wiler SW, Eum K, et al. Deletion of the Kv2.1 delayed rectifier potassium channel leads to neuronal and behavioral hyperexcitability. Genes Brain Behav
2014;13:394-408.

36. Misonou H, Mohapatra DP, Trimmer JS. Kv2.1: a voltage-gated $\mathrm{K}^{+}$ channel critical to dynamic control of neuronal excitability. Neurotoxicology 2005;26:743-52.

37. Schwarz JR, Glassmeier G, Cooper EC, Kao TC, Nodera H, Tabuena $\mathrm{D}$, et al. KCNQ channels mediate $I_{\mathrm{Ks}}$, a slow $\mathrm{K}^{+}$current regulating excitability in the rat node of Ranvier. J Physiol 2006;573:17-34.

38. Brown DA, Passmore GM. Neural KCNQ (Kv7) channels. Br J Pharmacol 2009;156:1185-95.

39. Schroeder BC, Kubisch C, Stein V, Jentsch TJ. Moderate loss of function of cyclic-AMP-modulated KCNQ2/KCNQ3 $\mathrm{K}^{+}$channels causes epilepsy. Nature 1998;396:687-90.

40. Otto JF, Yang Y, Frankel WN, White HS, Wilcox KS. A spontaneous mutation involving Kcnq2 (Kv7.2) reduces M-current density and spike frequency adaptation in mouse CA1 neurons. J Neurosci 2006;26:2053-9.

41. Catterall WA. Structure and regulation of voltage-gated $\mathrm{Ca}^{2+}$ channels. Annu Rev Cell Dev Biol 2000;16:521-55.

42. Catterall WA. Voltage-gated calcium channels. Cold Spring Harb Perspect Biol 2011;3:a003947.

43. Rossignol E, Kruglikov I, van den Maagdenberg AM, Rudy B, Fishell G. Cav2.1 ablation in cortical interneurons selectively impairs fast-spiking basket cells and causes generalized seizures. Ann Neurol 2013;74:209-22.

44. Heine M. Surface traffic in synaptic membranes. Adv Exp Med Biol 2012;970:197-219.

45. van Vliet EA, Aronica E, Redeker S, Boer K, Gorter JA. Decreased expression of synaptic vesicle protein $2 \mathrm{~A}$, the binding site for levetiracetam, during epileptogenesis and chronic epilepsy. Epilepsia 2009;50:422-33.

46. Raimondi A, Ferguson SM, Lou X, Armbruster M, Paradise S, Giovedi $S$, et al. Overlapping role of dynamin isoforms in synaptic vesicle endocytosis. Neuron 2011;70:1100-14.

47. Yamashita S, Chiyonobu T, Yoshida M, Maeda H, Zuiki M, Kidowaki S, et al. Mislocalization of syntaxin-1 and impaired neurite growth observed in a human iPSC model for STXBP1-related epileptic encephalopathy. Epilepsia 2016;57:e81-6.

48. Verhage M, Maia AS, Plomp JJ, Brussaard AB, Heeroma JH, Vermeer $\mathrm{H}$, et al. Synaptic assembly of the brain in the absence of neurotransmitter secretion. Science 2000;287:864-9.

49. Saitsu H, Kato M, Matsumoto N. Haploinsufficiency of STXBP1 and Ohtahara syndrome. In: Noebels JL, Avoli M, Rogawski MA, Olsen RW, Delgado-Escueta AV, editors. Jasper's basic mechanisms of the epilepsies. Bethesda (MD); National Center for Biotechnology Information (US); 2012. 
50. Toonen RF, Verhage M. Munc18-1 in secretion: lonely Munc joins SNARE team and takes control. Trends Neurosci 2007;30:564-72.

51. Toonen RF, Wierda K, Sons MS, de Wit H, Cornelisse LN, Brussaard A, et al. Munc18-1 expression levels control synapse recovery by regulating readily releasable pool size. Proc Natl Acad Sci U S A 2006;103:18332-7.

52. Reiner A, Levitz J. Glutamatergic signaling in the central nervous system: ionotropic and metabotropic receptors in concert. Neuron 2018;98:1080-98.

53. Farrant M, Nusser Z. Variations on an inhibitory theme: phasic and tonic activation of $\mathrm{GABA}_{\mathrm{A}}$ receptors. Nat Rev Neurosci 2005; 6:215-29.

54. Kodera H, Ohba C, Kato M, Maeda T, Araki K, Tajima D, et al. De novo GABRA1 mutations in Ohtahara and West syndromes. Epilepsia 2016;57:566-73.

55. Janve VS, Hernandez CC, Verdier KM, Hu N, Macdonald RL. Epileptic encephalopathy de novo $G A B R B$ mutations impair $\gamma$-aminobutyric acid type A receptor function. Ann Neurol 2016;79:806-25.

56. Lachance-Touchette P, Brown P, Meloche C, Kinirons P, Lapointe L, Lacasse $\mathrm{H}$, et al. Novel $\alpha 1$ and $\gamma 2$ GABAA receptor subunit mutations in families with idiopathic generalized epilepsy. Eur J Neurosci 2011;34:237-49.

57. Reid CA, Kim T, Phillips AM, Low J, Berkovic SF, Luscher B, et al. Multiple molecular mechanisms for a single $\mathrm{GABA}_{\mathrm{A}}$ mutation in epilepsy. Neurology 2013;80:1003-8.

58. Warner TA, Shen W, Huang X, Liu Z, Macdonald RL, Kang JQ. Differential molecular and behavioural alterations in mouse models of GABRG2 haploinsufficiency versus dominant negative mutations associated with human epilepsy. Hum Mol Genet 2016;25: 3192-207.

59. Qu S, Catron M, Zhou C, Janve V, Shen W, Howe RK, et al. GABA receptor $\beta 3$ subunit mutation D120N causes Lennox-Gastaut syndrome in knock-in mice. Brain Commun 2020;2:fcaa028.

60. Trevathan E, Mullens EL, Manasco P. Lamotrigine for generalized seizures associated with the Lennox-Gastaut syndrome. N Engl J Med 1998;339:851-2.

61. Eriksson AS, Nergardh A, Hoppu K. The efficacy of lamotrigine in children and adolescents with refractory generalized epilepsy: a randomized, double-blind, crossover study. Epilepsia 1998;39:495501.

62. Stefani A, Spadoni F, Bernardi G. Differential inhibition by riluzole, lamotrigine, and phenytoin of sodium and calcium currents in cortical neurons: implications for neuroprotective strategies. Exp Neurol 1997;147:115-22.

63. Glauser T, Kluger G, Sachdeo R, Krauss G, Perdomo C, Arroyo S.
Rufinamide for generalized seizures associated with LennoxGastaut syndrome. Neurology 2008;70:1950-8.

64. Bialer M, Johannessen SI, Kupferberg HJ, Levy RH, Loiseau P, Perucca E. Progress report on new antiepileptic drugs: a summary of the Fifth Eilat Conference (EILAT V). Epilepsy Res 2001;43:11-58.

65. Gilchrist J, Dutton S, Diaz-Bustamante M, McPherson A, Olivares $\mathrm{N}$, Kalia J, et al. $\mathrm{Na}_{\mathrm{v}} 1.1$ modulation by a novel triazole compound attenuates epileptic seizures in rodents. ACS Chem Biol 2014;9: 1204-12.

66. Perucca E, Cloyd J, Critchley D, Fuseau E. Rufinamide: clinical pharmacokinetics and concentration-response relationships in patients with epilepsy. Epilepsia 2008;49:1123-41.

67. Kim HJ, Kim SH, Kang HC, Lee JS, Chung HJ, Kim HD. Adjunctive levetiracetam treatment in pediatric Lennox-Gastaut syndrome. Pediatr Neurol 2014;51:527-31.

68. Dressler A, Trimmel-Schwahofer P, Reithofer E, Muhlebner A, Groppel G, Reiter-Fink E, et al. Efficacy and tolerability of the ketogenic diet in Dravet syndrome - Comparison with various standard antiepileptic drug regimen. Epilepsy Res 2015;109:81-9.

69. Chhun S, Troude P, Villeneuve N, Soufflet C, Napuri S, Motte J, et al. A prospective open-labeled trial with levetiracetam in pediatric epilepsy syndromes: continuous spikes and waves during sleep is definitely a target. Seizure 2011;20:320-5.

70. Muramatsu K, Sawaura N, Ogata T, Makioka N, Tomita K, Motojima T, et al. Efficacy and tolerability of levetiracetam for pediatric refractory epilepsy. Brain Dev 2017;39:231-5.

71. Custer KL, Austin NS, Sullivan JM, Bajjalieh SM. Synaptic vesicle protein 2 enhances release probability at quiescent synapses. J Neurosci 2006;26:1303-13.

72. Lynch BA, Lambeng N, Nocka K, Kensel-Hammes P, Bajjalieh SM, Matagne A, et al. The synaptic vesicle protein SV2A is the binding site for the antiepileptic drug levetiracetam. Proc Natl Acad Sci U S A 2004;101:9861-6.

73. Meehan AL, Yang X, McAdams BD, Yuan L, Rothman SM. A new mechanism for antiepileptic drug action: vesicular entry may mediate the effects of levetiracetam. J Neurophysiol 2011;106:1227-39.

74. Fukuyama K, Tanahashi S, Nakagawa M, Yamamura S, Motomura E, Shiroyama T, et al. Levetiracetam inhibits neurotransmitter release associated with CICR. Neurosci Lett 2012;518:69-74.

75. Hanada T, Hashizume Y, Tokuhara N, Takenaka O, Kohmura N, Ogasawara A, et al. Perampanel: a novel, orally active, noncompetitive AMPA-receptor antagonist that reduces seizure activity in rodent models of epilepsy. Epilepsia 2011;52:1331-40.

76. Auvin S, Dozieres B, Ilea A, Delanoe C. Use of perampanel in children and adolescents with Lennox-Gastaut Syndrome. Epilepsy 
Behav 2017;74:59-63.

77. Steinhoff BJ, Bacher M, Bast T, Kornmeier R, Kurth C, Scholly J, et al. First clinical experiences with perampanel-the Kork experience in 74 patients. Epilepsia 2014;55 Suppl 1:16-8.

78. Yelshanskaya MV, Singh AK, Sampson JM, Narangoda C, Kurnikova $\mathrm{M}$, Sobolevsky AI. Structural bases of noncompetitive inhibition of AMPA-subtype ionotropic glutamate receptors by antiepileptic drugs. Neuron 2016;91:1305-15.

79. Bourgeois BF. Felbamate. Semin Pediatr Neurol 1997;4:3-8.

80. Kleckner NW, Glazewski JC, Chen CC, Moscrip TD. Subtype-selective antagonism of $\mathrm{N}$-methyl-D-aspartate receptors by felbamate: insights into the mechanism of action. J Pharmacol Exp Ther 1999; 289:886-94.

81. Pisani A, Stefani A, Siniscalchi A, Mercuri NB, Bernardi G, Calabresi $P$. Electrophysiological actions of felbamate on rat striatal neurones. Br J Pharmacol 1995;116:2053-61.

82. Rho JM, Donevan SD, Rogawski MA. Mechanism of action of the anticonvulsant felbamate: opposing effects on $N$-methyl-D-aspartate and $\gamma$-aminobutyric acidA receptors. Ann Neurol 1994;35:22934.

83. Rogawski MA, Loscher W, Rho JM. Mechanisms of action of antiseizure drugs and the ketogenic diet. Cold Spring Harb Perspect Med 2016;6.

84. Wirrell EC, Laux L, Donner E, Jette N, Knupp K, Meskis MA, et al. Optimizing the diagnosis and management of Dravet syndrome: recommendations from a north American consensus panel. Pediatr Neurol 2017;68:18-34 e3.

85. Chiron C, Marchand MC, Tran A, Rey E, d'Athis P, Vincent J, et al. Stiripentol in severe myoclonic epilepsy in infancy: a randomised placebo-controlled syndrome-dedicated trial. STICLO study group. Lancet 2000;356:1638-42.

86. Ng YT, Conry JA, Drummond R, Stolle J, Weinberg MA, Investigators OVS. Randomized, phase III study results of clobazam in Len-
nox-Gastaut syndrome. Neurology 2011;77:1473-81.

87. Benarroch EE. $\mathrm{GABA}_{\mathrm{A}}$ receptor heterogeneity, function, and implications for epilepsy. Neurology 2007;68:612-4.

88. Quilichini PP, Chiron C, Ben-Ari Y, Gozlan H. Stiripentol, a putative antiepileptic drug, enhances the duration of opening of GAB$A_{A}$-receptor channels. Epilepsia 2006;47:704-16.

89. Poisson M, Huguet F, Savattier A, Bakri-Logeais F, Narcisse G. A new type of anticonvulsant, stiripentol. Pharmacological profile and neurochemical study. Arzneimittelforschung 1984;34:199-204.

90. Korff CM, Vulliemoz S, Picard F, Fluss J. Ohtahara syndrome or early-onset West syndrome? A case with overlapping features and favorable response to vigabatrin. Eur J Paediatr Neurol 2012;16: 753-7.

91. Cazorla MR, Verdu A, Montes C, Ayuga F. Early infantile epileptic encephalopathy with unusual favourable outcome. Brain Dev 2010;32:673-6.

92. Ben-Menachem E. Mechanism of action of vigabatrin: correcting misperceptions. Acta Neurol Scand Suppl 2011;192:5-15.

93. Petroff OA, Behar KL, Mattson RH, Rothman DL. Human brain $\gamma$-aminobutyric acid levels and seizure control following initiation of vigabatrin therapy. J Neurochem 1996;67:2399-404.

94. Wu Y, Wang W, Richerson GB. Vigabatrin induces tonic inhibition via GABA transporter reversal without increasing vesicular GABA release. J Neurophysiol 2003;89:2021-34.

95. Davis R, Peters DH, McTavish D. Valproic acid. A reappraisal of its pharmacological properties and clinical efficacy in epilepsy. Drugs 1994;47:332-72.

96. Vassella F, Rudeberg A, Da Silva V, Pavlincova E. Double-blind study on the anti-convulsive effect of phenobarbital and valproate in the Lennox syndrome. Schweiz Med Wochenschr 1978;108:7136.

97. Schmidt D, Bourgeois B. A risk-benefit assessment of therapies for Lennox-Gastaut syndrome. Drug Saf 2000;22:467-77. 